\title{
School Based Factors Influencing Pupils' Wastage in Public Primary Schools in Mwala Division, Mwala District, Kenya
}

\author{
Doi:10.5901/mjss.2015.v6n2s1p194
}

\author{
Kamwitha Anastasia Muthanje
}

\begin{abstract}
The information from Mwala District Development Plan 2008-2012, the DEOs inputs in her meeting with teachers in the division and the performance, it is clear that elements of wastage exists in public primary schools in Mwala Division, Mwala District. This gap is further observed in the Area Education Officer's (AEO) enrolment records of the period 2005-2012. The records show that cohort analysis of Grade 8 of year 2005-2012, enrolment in Grade 1 in the year 2005 was 2146. By the year this Grade 1 pupils was completing Grade 8 in the year 2012, the enrolment was 1670. This was a difference of 476 pupils which accounted to $22.18 \%$. The difference may have been due to dropout and repetition of pupils in the cause of this progression from one grade to the other. This shows low completion rates, hence wastage in education. The high enrolment in Grade 1 may have been caused by the inception of Free Primary Education (FPE) in 2003 by the government which allowed out-of-school children back to school without any payments for tuition. This made big number of out-of-school children to go back to school though the number reduced as time went on.
\end{abstract}

\section{Background to the Study}

Education is both consumption and an investment. Education equips people with skills and knowledge that enable them to increase their productive capacities and hence receive higher earnings. World Bank (1980) affirms that education is a productive investment in human capital. Education is not only a basic human right, but also a basic component of social and economic development. In the planned investments education pay great economic dividends, especially in the poor countries. This contributes to social progress (Psacharopolous and Woodhall 1985).

According to United Nations Educational, Scientific and Cultural Organizations (UNESCO), (1998), Education is seen as a means of promoting equality; though at times contribute to inequality. It further indicates that in today's knowledge based society; those who obtain a good basic education continue to learn throughout their lives to remain economically viable. Those lacking a solid educational foundation are destined to fall further and further behind. The Universal Declaration of Human Rights adopted by the United Nations in 1948, stated that 'everyone has a right to education. This assertion has subsequently influenced international conferences and normative texts where it has been reaffirmed and its goal sought to be achieved.

The Dakar Framework for Action called upon countries to adopt policies and practices that were to ensure 'Universal access to, and completion of primary education by the year 2000'. It also urged countries to pursue 'Improvement in learning achievement such that an agreed percentage of an appropriate age cohort that is 80 percent of 14 year- olds surpassed or attained a defined level of necessary educational achievement (UNESCO, 1998).

According to UNESCO (1998), wastage is about missed opportunities for individuals, communities, entire nations and regions of the world. It deprives the developing countries of the ability to make the most efficient use of scarce resources and it takes its greatest toll on the most vulnerable groups in society. Wastage is evident in the 84 million primary- school age children who are not enrolled in school, of which three out of five are girls. Wastage also concerns the pupils who complete the primary cycle but fail to gain the intellectual, social, cultural and ethical knowledge and skills that schooling should provide. It also concerns children who complete their primary school education without acquiring an adequate mastery of reading. Children who never gain access to school and those who never enrol but do not attain an adequate level of learning constitute a tragic wastage of the human, social, and economic potential of the countries concerned. Wastage is about pupils who start school but drop out before they reach sustainable literacy and numeracy level. Also wastage occurs when pupils have to repeat grades. In developing countries especially, this is often a prelude to drop- out.

Dropout and repetition, results from limited learning opportunities in overcrowded classrooms with insufficient learning materials and under-qualified teachers. Also household poverty, inequalities linked to language and ethnicity, and rural- urban differences all contribute to the problem (Alexander, 2008).

In Chile inefficiency in schools was experienced due to inadequacy of textbooks, negative attitude of teachers 
towards textbooks and inability of poor children to buy books, even when teachers wished to use them (Heyneman, Farrel, and Sepulveda-Stuardo, 1978). In Mexico, the government devised a policy on provision of free textbooks for primary school pupils in order to improve educational efficiency and equity. This raised academic standards and increased the efficiency of production. Lack of instructional materials such as textbooks was experienced in Philippines and Nicaragua. The Philippine government with the assistance of the World Bank launched US\$37 million textbook project to provide textbooks and to increase the ratio between textbook and pupils from 1:10 to 1:2 whereas in a sub sample of schools, ratio of 1:1 was realized in teacher training in the use of textbooks. The increase in the number of textbooks had a sizable impact on pupil achievement (Psacharopoulos and Woodhall Maureen 1985).

In Ghana, Madagascar, Morocco, Niger, Senegal, Sierra Leone, and Uganda, school wastage was rampart in that the recruitment and retention of teachers remained a challenge particularly where resources were limited. Schools resorted to hiring teachers on limited contracts, drawn from the community, outside the public service pay and tenure structures, as a way to provide the human resources needed to cope with rapid expansion (Antonowicz, Lesne', Stassen, and Wood, 2010). This was solved by upgrading of existing teachers, particularly licensed and paraprofessional teachers. This teacher upgrading contributed in different ways to ensuring that there was enough qualified teachers for primary and secondary students (Research on Poverty Alleviation (REPOA, 2008).

In Senegal, dropout was rampart. The survival rates to grade 5 for children who started school two years late being ten percent. This was lower than for children who started on time. Consequently, repetition rates for underage or overage children tended to be much higher than those who started on time. This was curbed through applying policies such as fees abolition, more stringent regulations on age limits and alternative programmes for over-age children. This was to concur with the prerequisites for Universal Primary Education (UPE) which states that children should start school on time in order to complete a full primary cycle at the appropriate age since delayed school entry can lead to dropout and is also associated with repetition (EFA Global Monitoring Report, 2011).

In Tanzania wastage was experienced where Teacher Pupil Ratio (TPR) was a factor on student performance. At national level, TPR stood at one teacher per 40 students. At Dar es Salaam district level TPR ranged from 29 to 121 pupils for one teacher. The ministry sought to improve these TPRs by allocating the deployment of anticipated new teacher graduates based on districts. This ensured that those districts which had low TPRs received more teachers while those that had high TPRs received fewer. Districts which had TPRs of less than 45 students per teacher were not allocated any new teacher (REPOA, 2008).

In Kenya, a significant improvement in access to primary education was witnessed during the inception of Free Primary Education (FPE) in 2003 by the government. The primary schools Net Enrolment Rate (NER) rose from 79.8 per cent in 2003 to 91.6 percent in 2007. This was a commendable increase when compared to the targeted NER of 84.4 per cent for 2007, an increase of 7.2 percentage points (EMIS, Ministry of Education, 2007). Primary school completion rate, 2002-2008 shows that the country has not yet realized the $100 \%$ completion rates due to wastage being experienced in primary schools (Republic of Kenya 2007). Starting school on time will help complete primary education because delayed school entry is closely associated with increased risk of dropout. Late entry is associated with higher rates of repetition in early grades, which can increase the cost of education to households and weaken the internal efficiency of the education system (EPDC, 2008).

According to Mwala District development plan 2008-2012, the dropout rates are 3.9\% and average teacher-pupil ratio is 1:36. There is also a staff imbalance. There are a total of 62 public primary schools, 470 teachers, and 16,998 pupils in the division. The performance is average (Republic of Kenya, 2009). Below is KCPE performance of the Division from Year 2007-2011. This is an indication that there is wastage in Mwala Division and thus the need to assess the school based factors influencing this wastage and possible solutions to curb it in the Division.

\section{Conceptual Framework}

The conceptual framework shown in figure 1.1 captures school based factors and their influence on dropout, repetition, and completion. 


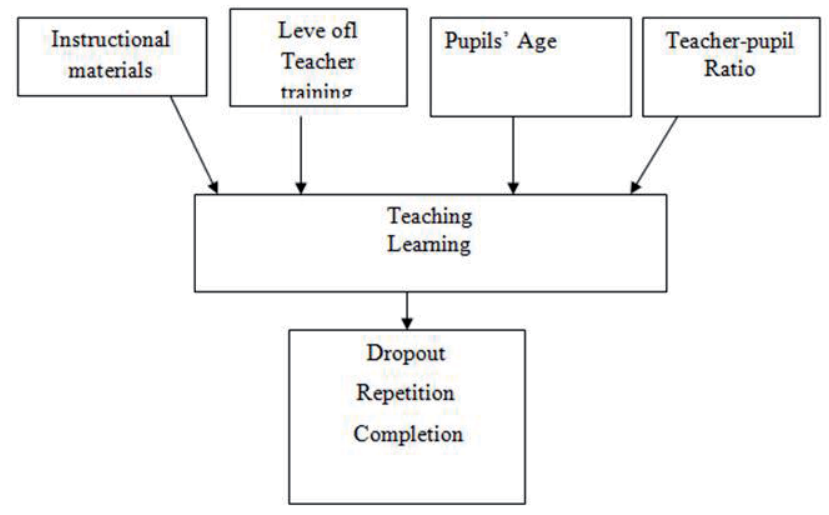

The figure shows the interrelationship between various factors thought to cause dropout and repetition in an education system. Instructional materials such as textbooks enhance pupils' achievements and therefore reduce repetition. The use of textbooks raises academic standards and increases the efficiency of schools. When instructional materials are not provided, the result is low educational achievement which results in repetition and dropout of pupils. Thus repetition impacts on the primary school completion rates. The higher the repetition rate the fewer the children that complete primary schooling and the more likely there is of some children who have repeated going to dropout. The teacher is the single most important factor in improving pupils' achievement outcomes. Unattractive teaching methods due to lack of teacher's inadequacy results in pupils dropping out of schools due to low academic achievements. Getting pupils to school at advanced age can contribute to low academic achievement. This can come about as a result of being preoccupied with things that suit their age such as early marriages and being employed at meagre salaries to help their poor families. Under-age pupils may not get the concept taught in their respective grades in various subjects thus both ages can result to dropout and low completion rates. In overcrowded classrooms, class management can be problematic and learning can be affected. Teachers may find it difficult to offer individual attention to pupils and this can result in those who feel neglected not performing well and eventually these results to repetition and consequently dropout.

\section{Research Design}

The study adopted descriptive survey design to investigate the school based factors influencing pupils' wastage in public primary schools. Descriptive survey is a method of collecting information by interviewing or administering a questionnaire to a sample of individuals (Orodho, 2003). The study enabled the researcher to determine the insight into intensive, descriptive and holistic analysis of the variables on dropout and repetition among primary school pupils.

This study used questionnaires, focus group discussions and document analysis. The researcher used questionnaires to solicit information from the head teachers and teachers. Mugenda and Mugenda (1999), assert that a questionnaire is a written set of questions to which the subjects respond in writing. The questionnaires had both closed and open ended questions and the matrix questions. The questionnaire was used to gather information at school level on reasons for repetition and dropout of pupils and possible effort they are making to curb them in future.

Focus Group Discussion guide was used to gather information from class five, six, and seven. Repeaters from classes 5 to 7 and those pupils who dropped out of school and came back were sampled from schools under study to participate in the FGD since they were in a position to give reasons why they repeated grades and why they had dropped out of school earlier.

The researcher examined school records and other documents that were relevant, such as admission records, completion registers, with a view to obtain information on dropouts and repetition in the sampled schools. Document analysis of merit lists helped to note pupils who repeated grades especially at the beginning of the year, and Form A to get teachers' qualification profile.

\section{Data Presentation, Analysis and Interpretation}

\subsection{Provision of instructional materials' influence on pupils' repetition in Public primary schools}

Grade repetition is a proportion of children who do not master the curriculum because school quality was insufficient. A 
high level of grade repetition is a sign of dysfunctional school system often exacerbating dropout and resulting in overcrowded schools. This study sought to examine how provision of instructional materials affected pupils' repetition.

The majority of the teachers $(65.3 \%)$ indicated that there were no adequate textbooks for all pupils in every subject in class. The focus group discussion with both the repeaters and the drop out also established that there were no adequate textbooks and other instructional materials. The enquiry on the ratio of books to pupils per class from the teachers. The yielded data presented in the table below.

\begin{tabular}{|c|c|c|c|c|c|c|c|c|c|c|}
\hline \multirow[t]{3}{*}{ Class } & \multicolumn{8}{|c|}{ Ratio of Maths books with number of pupils } & \multirow{2}{*}{\multicolumn{2}{|c|}{ Total }} \\
\hline & \multicolumn{2}{|c|}{$1: 1$} & \multicolumn{2}{|c|}{$1: 2$} & \multicolumn{2}{|c|}{$1: 3$} & \multicolumn{2}{|c|}{$1: 4$} & & \\
\hline & $\mathbf{F}$ & $\mathbf{P}$ & $\mathbf{F}$ & $\mathbf{P}$ & $\mathbf{F}$ & $\mathbf{P}$ & $\mathbf{F}$ & $\mathbf{P}$ & $\mathbf{F}$ & $\mathbf{P}$ \\
\hline 1 & 0 & 0 & 1 & 8.3 & 5 & 41.7 & 6 & 50.0 & 12 & 100.0 \\
\hline 2 & 0 & 0 & 4 & 30.8 & 4 & 30.8 & 5 & 38.5 & 13 & 100.0 \\
\hline 3 & 0 & 0 & 1 & 5.9 & 9 & 52.9 & 7 & 41.2 & 17 & 100.0 \\
\hline 4 & 0 & 0 & 3 & 16.7 & 6 & 33.3 & 9 & 50.0 & 18 & 100.0 \\
\hline 5 & 0 & 0 & 3 & 16.7 & 4 & 22.2 & 11 & 61.1 & 18 & 100.0 \\
\hline 6 & 1 & 5.9 & 4 & 23.5 & 5 & 29.4 & 7 & 41.2 & 17 & 100.0 \\
\hline 7 & 0 & 0 & 1 & 7.7 & 5 & 38.5 & 7 & 53.8 & 13 & 100.0 \\
\hline 8 & 0 & 0 & 2 & 20.0 & 2 & 20.0 & 6 & 60.0 & 10 & 100.0 \\
\hline Total & 1 & 8 & 19 & 16.1 & 40 & 33.9 & 58 & 49.2 & 118 & 100.0 \\
\hline
\end{tabular}

From table, on average the ratio of books to pupils in all classes the ratio was 1:4 except in class 3 which had a ratio of 1:3. This implies that in most of the schools Mathematics books are inadequate. This concurs with Mbilinyi (2003) who found out that in most cases books, charts, maps and other teaching/ learning materials are not adequate in schools. This situation may pave way for students' low participation leading to low performance, in mathematics.

\subsection{Pupil's repetition on class}

The teachers were asked to indicate the number of pupils who repeated in the class for the year 2012 because they lacked textbooks and other instructional materials. The results are as shown in Table 4.13.

Table 4.13. Number of pupils repeating in class for the year 2012 because they lacked textbooks and other instructional materials

\begin{tabular}{ccc}
\hline \hline Number of pupils repeating & Frequency & Percent \\
\hline $1-3$ & 6 & 5.1 \\
$4-6$ & 6 & 5.1 \\
$7-9$ & 2 & 1.7 \\
10 and above & 2 & 1.7 \\
None & 103 & 87.3 \\
\hline Total & 118 & 100.0 \\
\hline
\end{tabular}

The majority of the teachers (87.3\%) indicated that no pupils in their class had repeated for lack of textbooks. From the headteachers questionnaires, the headteachers were asked to indicate the cases of pupils repeating grades in their school because they lacked instructional materials like textbooks. The results are as shown in Table 4.14.

Table 4.14. Distribution of headteachers with cases of pupils repeating grades in their schools

\begin{tabular}{ccc}
\hline \hline & Frequency & Percent \\
\hline Yes & 14 & 22.2 \\
No & 4 & 77.8 \\
\hline Total & 18 & 100.0 \\
\hline
\end{tabular}

The majority of the headteachers (77.8\%) felt that there were no cases of pupils in their schools repeating because of the lack of instructional materials. The headteachers affirmed that pupils made use of the available instructional materials. The pupils also indicated that they used the instructional materials available. 
The conclusion drawn on provision of instructional material's influence on pupils repetition, majority of the teachers noted that there were inadequate textbooks but this did not make pupils from their classes to drop out of school as indicated by the majority of the teachers (87.3\%) and 77.8 percent of the headteachers.

\subsection{How level of teacher training affects pupils' dropout in public primary schools}

The researcher wanted to know from the teachers whether the level of teacher training affects pupils' dropout in public primary schools. First the researcher asked the teachers to explain whether they used the skills gained in training to handle pupils in their class. The results are as shown in table 4.15.

Table 4.15. The skills gained in training help to handle pupils in their class

\begin{tabular}{lcc}
\hline \hline Useful skills & Frequency & Percent \\
\hline Identifying learners and their abilities & 86 & 72.9 \\
Grouping learners according to their abilities & 68 & 57.6 \\
Give pupils necessary attention & 29 & 24.6 \\
Motivate pupils & 20 & 16.9 \\
Help in using right methodology- child-centred approaches & 17 & 14.4 \\
No Response & 15 & 12.7 \\
$\mathrm{~N}=118$ & &
\end{tabular}

From table $4.9,72.9 \%$ of the teachers noted that the skills helped teachers identify the different learners and their abilities which include special need learners. This shows that they were able to apply the methods they learnt during training such as child-centred approach. These results agrees with (Darling-Hammond et al., 2008) who noted that child-centered pedagogies include models of teaching and learning that are project-based, collaborative, foster knowledge building, require self-regulation and assessment, and are both personalized (allowing for pupils choice and relevance to the individual pupil) and individualized (allowing pupils to work at their own pace and according to their particular learning needs).

\subsection{Level of teachers training}

From the document analysis the level of teachers' training is presented in Table 4.16.

Table 4.16. Level of teachers training

\begin{tabular}{ccc}
\hline \hline & Frequency & Percent \\
\hline P1 Teacher & 60 & 35.7 \\
ATS 1 Teacher & 14 & 8.3 \\
ATS 2 Teacher & 5 & 3.0 \\
ATS 3 Teacher & 25 & 14.9 \\
ATS 4 Teacher & 24 & 14.3 \\
Graduate & 2 & 2.9 \\
Untrained & 27 & 16.1 \\
Trained unemployed & 11 & 6.6 \\
\hline Total & 168 & $\mathbf{1 0 0 . 0}$ \\
\hline
\end{tabular}

Table 4.10, indicated that 35.7 percent of the teachers were P1 Teachers, while 16.1 percent of them were untrained and 14.9 percent of the teachers had ATS 3. From these findings its clear that the majority of the teachers (83.9\%) were trained hence this could not be a contributing factor to pupils drop outs.

\subsection{Handling of subject by teachers}

From the focus group discussion, the majority of the repeaters and drop outs (78.2\%) agreed that the teachers were comfortable with the subjects they handled; there was a good relationship between the pupils and the teachers. Only 21.8 percent of the drop outs indicated that it was because of their poor relationship with their teachers that they dropped out 
of school.

\subsection{Pupils dropping out}

The study enquired whether there were pupils who drop out of class because of the teachers. The results are as shown in Table 4.17.

Table 4.17. Presence of pupils dropping out of class

\begin{tabular}{ccc}
\hline \hline & Frequency & Percent \\
\hline Yes & 33 & 28.0 \\
No & 85 & 72.0 \\
\hline Total & 118 & 100.0 \\
\hline
\end{tabular}

The majority of the teachers (72.0\%) reported that in their classes there were no drop outs. The researcher observes that there were different reasons as to why pupils drop out of school. Some of the reasons given in regard to the level of teacher training includes: overage pupils hence they were uncomfortable to learn with their younger siblings. The other reasons are due to poverty / socio-economic reasons, excessive work in classes, parent negligence, parents also fail to participate in their children schooling, lack of motivation from parents and the society, some orphans have no one to care for them, teachers in school are inadequate, and others drop out due to their own failure that is pregnancy on girls, drugs and substance abuse and influence of sand sellers but not because of teachers level of training.

From the focus group discussions of the repeaters, it was indicated that most of them who had a bad relationship with the teachers were overage. The overage pupils did not like to be beaten up by teachers. Lack of money to pay PTA teachers by the school due to poverty and many siblings in a family made them drop out of school. The overage pupils also left school because the young pupils looked down on them as a result of poor marks they got and being forced to be in classes (repeating) they did not like. These made them loose morale to be in school. From the discussion above the researcher concluded that there is no effect on teachers training on pupils' repetition. The teachers training did not contribute to pupils drop out of school as indicated by 83.9 percent of the teachers. There are other factors that encourage pupils drop out.

\subsection{How pupils' age affects dropouts in public primary schools.}

The study sought to know whether there were overage and underage pupils in class. The results are as shown in Table 4.18.

Table 4.18. Overage and underage pupils in class

\begin{tabular}{ccccc}
\hline \hline & \multicolumn{2}{c}{ Overage } & \multicolumn{2}{c}{ Underage } \\
\hline \hline Yes & Frequency & Percent & Frequency & Percent \\
\hline No & 70 & 59.3 & 70 & 59.3 \\
\hline Total & 48 & 40.7 & 48 & 40.7 \\
\hline
\end{tabular}

The majority of the teachers (59.3\%) noted that there were overage and underage pupils in their classes. The presence of both overage and underage pupils causes different challenges to teachers when handling them.

The study wished to identify how the teachers treated both the overage and underage in the same classes. Some of the methods used included, guidance and counselling of both, accepting them and encouraging them, giving them responsibilities such as the class monitor, keeping the class neat, clean, motivating them to work extra hard, use of different techniques to encourage them to remain in school, giving them special attention, treating them like other pupils, rewarding them and making them feel appreciated by everyone.

From headteachers questionnaire the researcher wanted to know whether there were cases of dropout due to overage or underage in school. The majority of the headteachers (66.7 percent) noted that there was no drop out due to overage and underage. 
Since admission was done as required at 4 years in pre-school and 6 years in class one then as the majority of the headteachers noted that there was no drop out in their school due to overage and underage. Hence age is not a determinant of pupils dropping out of school and repetition in classes.

\subsection{The extent to which teacher-pupil ratio affects pupils' dropout in public primary schools}

A low pupil-teacher ratio is likely to enable teachers to give individual attention to the pupils, and therefore increase the interaction. With this in mind, the researcher wished to establish whether teacher-pupil ratio's influenced pupils' dropout in the public primary schools. The responses on whether teachers' paid individual attention to all pupils in class are in Table below

Able to pay individual attention to every pupil in class

\begin{tabular}{ccc}
\hline \hline & Frequency & Percent \\
\hline Yes & 69 & 58.5 \\
No & 49 & 41.5 \\
\hline Total & 118 & 100.0 \\
\hline
\end{tabular}

From table, the majority of the teachers (58.5\%) said they were able to pay individual attention to every pupil in class. The majority of the teachers (96.6\%) said that there were no pupils who dropped out of school for lack of individualized attention from the teachers. The headteachers were asked whether there are pupils who drop out of school due to overcrowding in classes. The Majority of the headteachers (88.9\%) said that pupils did not drop out of school due to overcrowding. The suggestions given by the headteachers and teachers contradict with those of Huha (2005) who noted that teachers working in a situation where teacher/pupil ratios are high would be expected to be overworked and lack time to prepare their work hence this can result to drop out.

\subsection{Discipline cases and curbing dropout}

The headteachers were asked to indicate how teachers handled discipline cases in their schools. In the case of discipline all the headteachers noted that teachers in their schools handle pupils with respect and care especially when it comes to discipline. This prompted the researcher to enquire from the headteachers whether there was guidance and counselling as a measure of curbing dropout among the pupils. The findings show that the majority of the headteachers (83.3\%) cited the availability of guidance and counselling in their school as a measure used to curb the dropout of pupils. The researcher enquired to know how effective the same was as a measure to curb dropout of pupils. The majority of the headteachers (83.3\%) agreed that guidance and counselling was an effective measure of curbing dropout of pupils.

From the teachers findings it is clear that pupils drop out rate and repetition is not determined by the teacher-pupil ration but are other factors that affect repetition and drop out. The study established that guidance and counselling was found to be effective in curbing the high rate of drop out among pupils as indicated by the headteachers.

\section{Conclusions}

The following conclusions can be drawn from the findings of the study:

Provision of instructional materials influenced pupils to repeat, this was because there are no adequate textbooks for all pupils in a class. This was reported by the repeaters, drop out who resumed classes and also the headteachers who noted that their schools did not have adequate instructional materials. Hence there should be an established system in provision of instructional materials in all primary schools in Kenya.

The level of teacher training did not influence pupils drop out of school. There were other reasons that contributed to pupils drop out; such as shortage of teachers, age of the pupils learning with their juniors make them uncomfortable, poverty/ socio-economic reasons, excessive work in classes and parents negligence.

Pupils' age does not influence pupil's dropout. The reasons as to why pupils drop out of school were peer pressure, work as labourers, family problems and low self esteem among others. Guidance and counselling department should come in to curb such reasons that make pupils drop out of school. The parents should also be requested to start participating in the children's learning activities. The recommend age of pupils at admission to class 1 is 6-7years.

Although some teachers were able to give individual attention to every pupil in class, there were some that had no much time to be able to attend to all pupils. This was because the classes are large and time for the lessons is limited. 
The Teachers service commission should employ more teachers to remove overcrowding in classes. Overcrowded classes make the teachers be overworked hence low performance.

\section{References}

Abagi, O.\& Odipo, G. (1997). Efficiency of primary Education in Kenya. Situational Analysis implications. IPAR discussion paper No. 00497)95, N, Nairobi: Regal Press.

Alexander, R. (2008). Education for All, the Quality imperative and the problem of Pedagogy. Brighton, UK, University of Sussex, Centre for International Education, Consortium for Research on Educational Access, (CREATE Pathways to Access Research Monograph, 20.)

Antonowicz, L., Lesne', F., Stassen S.,\& Wood, J. (2010). Africa education watch: Good governance lessons for primary education. Transparency International. Retrieved February $16^{\text {th }}$, 2012, from http://www.transparency,org/content/download//50164/802844/ Africa-Education-Watch-eng.pdf.

Best, J \& Khan. (1998). Research in Education. New Jersey: Englewood Cliffs.

Best, J.W. and Kahn, J.V. (2002). Research in Education. (7th Ed). New Dheli: Prentice Hall of India.

Borg, R, W, and Gall, D, M. (1989). Educational Research: An Introduction. New York: Longman Inc.

Boyle, S., Brook, A., Mace, A., and Sibbons, M. (2002). Reaching the Poor: The "Costs"of sending children to school-A six Country Comparative Study. London, UK Department for international Development. (Education Research Paper 47)

Chinnapat Bhumirat, Sonri Kidchanapanish, Pansri Arunrugrueng, Rayawan Shinatrakool (1987), Research \& Evaluation on the Quality of Primary Education.

Education Policy and Data Centre, 2008. Pupil performance and age: a study of promotion, repetition and dropout rates among pupils in four age groups in developing countries. Background paper for EFA Global Monitoring Report 2009.

EFA Global Monitoring Report. (2005). UNESCO. FAWE. (2002). The ABC of Gender Responsive Education Policies; Guidelines for Analysis and Planning. Forum for African Women Educationists, FAWE Newsletter , Nairobi.

EFA Global Monitoring Report. (2005). UNESCO.

EFA Global Monitoring Report.. (2011). UNESCO.

Eshiwani, G. S. (1984). Factors Influencing Performance among Primary and Secondary Schools in Western Province. Policy Study (Kenyatta University College). Bureau of Educational Research.

FAWE (2002). The ABC of Gender Responsive Education Policies: Guidelines for Analysis and Planning. Forum for African Women Educationists, FAWE Newsletter, Nairobi.

Gay L, R, (1976). Education Research, Competence for Analysis and Application, Charles Merril Publishing Co. Columbus.

Huha, J. (2003). A Comparative Study of Factors that Influence Performance in Kenya Certificate of Primary Examination (K.C.P.E.) in Public and Private Schools in Karai Location of Kikuyu Division, in Kiambu. University of Nairobi: Unpublished Thesis.

Hynemann, S, P., \& Farrel, J. P., Sepulveda, S.A. (1978). Textbooks and achievements: What we know. World Bank Staff Working paper 298, Washington, D.C; World Bank.

Kiess, H. O. \& Bloomquist, D. W. (1985). Psychological Research Methods: A Conceptual Approach. Boston; Allyn and Bacon.

Krueger. R, A\& Casey M, A. (2000). Focus Groups. A Practical Guide for Applied Research, 3 ${ }^{\text {rd }}$ ed. Thousand Oaks. CA: Sage Publications.

Lewin, K, M. (2009). Access to Education in sub-Saharan Africa: Patterns, problems and Possibilities. Comparative Education, 45(2): 151-174.

Little, A.W.(2008). Size matters for EFA, CREATE Pathways to AccessNo.26 Consortium for Research on Educational Access. Transitions and Equity; University of Sussex.

Lockheed, E.M ., Verspoor , A. M. and Associates (1991): Improving Primary Education in Developing Countries: Oxford University Press.

Mace, J. (1979). Themes, Concepts and Assumptions in Economics of education Policy, U.K.: The Open University Press.

Mbilinyi, D. S. (2003). Equity in learning: The Gender Dimension. ADEA Biennial Meeting, Mauritius: Grand Baie.

Mugenda, D. M and Mugenda, A .G. (1999), Research Methods; Qualitative and Quantitative Approaches. Nairobi: Acts Press.

Nyawara, A K. A. (2007). Factors that influence pupils dropout in public primary schools in Asego division, Homa Bay district. Unpublished M. Ed. Project, Nairobi; University of Nairobi.

Ojiambo, P. O. (2009). Quality of Education and its Role in National Development: A Case study of Kenya's Educational Reforms. Kenya Studies Review: 1, 1, 133-149.

Orodho, J. A. \& Kombo, D. K. (2002). Research methods. Nairobi: Kenyatta University, Institute of Open Learning.

Orodho, J, A. (2005). Techniques of Writing Research Proposal and Projects in Education and Social Sciences (2 ED). Nairobi: Kanezja HP Entreprises.

Patton, M. Q. (2002). Qualitative evaluation and research Methods (3rd ed.).Thousand Oaks, CA: Stage Publications, Inc.

Philips, H. M. (1975). Basic Education, A World Challenge, measures and innovations for children and youth in developing countries, John Wiley \& Sons Ltd, Pitman Press, Great Britain.

Psacharopoulos G \& Woodhall M., (1985). Education for Development: An Analysis of Investment Choices, Washington: Oxford University Press.

Republic of Kenya (2007), Education Statistical Booklet: Nairobi: Government Printer. 
Republic of Kenya (2009). District Development Plan 2000-2012: Nairobi: Government Printer.

Research on Poverty alleviations The impact of Reforms on the Quality of Primary Education in Tanzania, (REPOA) (2008). E\&D Publishing Ltd, Dar es Salaam, Tanzania.

Sabates, R., Akyeameong, K., Westbrook, J, Hunt, F. (2010). School-dropout patterns, causes, changes and policies .Background paper for EFA Global Monitoring Report 2011.

Seetharamus A. S \& Usha Devi. 2007). Education in Rural Areas, constraints and Prospects, S.B. Nangia APH Publishing Corporation, New Delhi.

Sifuna, D.N. (2005). Increasing Access and. Participation of Pastoralist. Communities in Primary. Education in Kenya. International. Review of. Education, Vol. 3.

Theuri, A. W. (2004).An Analysis of Internal Efficiency in Second Level Learning Institutions in Slum Areas of Nairobi Province, Kenya. Unpublished Med Thesis, Kenyatta University.

Warren, C.B \& Stocks M. T. (1985). Investing in Development: Lessons of World Bank experience. The World Bank; Oxford University Press.

World Bank (1980), The Education Dilemma, policy issues for developing countries in the 1980s, A. Wheaton \& Co. Ltd, Great Britain. UNESCO, (1998). Wasted Opportunities When Schools Fail, Repetition and Dropout in Primary Schools; Paris: UNESCO Office.

UNESCO, (2011). the hidden Crisis: Armed Conflict and Education, Paris, UNESCO Office.

Yodsaeranee, S. (1985). Problems in the implementation of 1978 primary education curriculum according to administrators and teachers under the office of Provincial Primary Education in Nakorn Sawan. Unpublished master's thesis. Bangkok: Sinakharinwirot University. 